\title{
Results of an aqueous source term model for a radiological risk assessment of the Drigg LLW Site, U.K.
}

Article

Accepted Version

Small, J. S., Humphreys, P. N., Johnstone, T. L., Plant, R., Randall, M. G. and Trivedi, D. P. (1999) Results of an aqueous source term model for a radiological risk assessment of the Drigg LLW Site, U.K. MRS Proceedings, 608 (129). ISSN 1946-4274 doi: https://doi.org/10.1557/PROC-608-129 Available at https://centaur.reading.ac.uk/16608/

It is advisable to refer to the publisher's version if you intend to cite from the work. See Guidance on citing.

To link to this article DOI: http://dx.doi.org/10.1557/PROC-608-129

Publisher: Materials Research Society

All outputs in CentAUR are protected by Intellectual Property Rights law, including copyright law. Copyright and IPR is retained by the creators or other copyright holders. Terms and conditions for use of this material are defined in the End User Agreement.

www.reading.ac.uk/centaur 
Central Archive at the University of Reading

Reading's research outputs online 


\title{
RESULTS OF AN AQUEOUS SOURCE TERM MODEL FOR A RADIOLOGICAL RISK ASSESSMENT OF THE DRIGG LLW SITE, UK.
}

\author{
J.S. SMALL, P.N. HUMPHREYS, T.L. JOHNSTONE, R. PLANT, M.G. RANDALL, AND \\ D.P. TRIVEDI \\ BNFL Research \& Technology, Risley, Warrington, WA3 6AS, UK.
}

\begin{abstract}
A radionuclide source term model has been developed which simulates the biogeochemical evolution of the Drigg low level waste (LLW) disposal site. The DRINK (DRIgg Near field Kinetic) model provides data regarding radionuclide concentrations in groundwater over a period of 100,000 years, which are used as input to assessment calculations for a groundwater pathway. The DRINK model also provides input to human intrusion and gaseous assessment calculations through simulation of the solid radionuclide inventory. These calculations are being used to support the Drigg post closure safety case. The DRINK model considers the coupled interaction of the effects of fluid flow, microbiology, corrosion, chemical reaction, sorption and radioactive decay. It represents the first direct use of a mechanistic reaction-transport model in risk assessment calculations.
\end{abstract}

\section{INTRODUCTION}

Disposals to the UK LLW site at Drigg, owned and operated by BNFL, are authorised by the Environment Agency under the terms of the Radioactive Substances Act 1993. A post closure radiological safety assessment (PCRSA) is being prepared to support the safety case for the Drigg site. An integral part of the PCRSA is the DRINK source term model which simulates the biogeochemical evolution of the Drigg near surface site. DRINK provides radionuclide concentrations within the near field which are input as radionuclide fluxes to a groundwater assessment model. Simulated activities of radionuclides remaining in the near field are used for the calculation of impacts associated with potential human intrusion. In addition to quantitative model inputs, DRINK helps provide a phenomenological understanding of the behaviour of the site over extended periods of time, which is a requirement of the regulatory guidance.

The Drigg site uses two disposal systems: 1) An original system operated from 1959 to 1988 comprising a series of parallel trenches excavated into glacial clays, back filled with LLW and covered with an interim water resistant cap. 2) Current disposal of compacted waste placed in steel ISO-freight containers, with void space filled with a highly fluid cement based grout. These containers are then disposed of in a series of open concrete vaults. Figure 1 illustrates the disposition of the two disposal systems. Drigg LLW contains a large proportion of cellulosic waste together with disposed steel and contaminated soil. Radionuclides with highest activities in the inventory include ${ }^{3} \mathrm{H},{ }^{241} \mathrm{Pu},{ }^{137} \mathrm{Cs},{ }^{234} \mathrm{U}$ and ${ }^{90} \mathrm{Sr}$. The long-lived radionuclides ${ }^{238} \mathrm{U}$ and ${ }^{232} \mathrm{Th}$ have the highest molal concentration.

This paper outlines the functionality of the DRINK mechanistic source term model and gives examples of its output which are used as direct inputs to assessment calculations. Input data used in these model runs represents independently compiled data sets, which serve as a base case for subsequent sensitivity studies to investigate data uncertainties whose effect will be considered by the PCRSA calculations. 


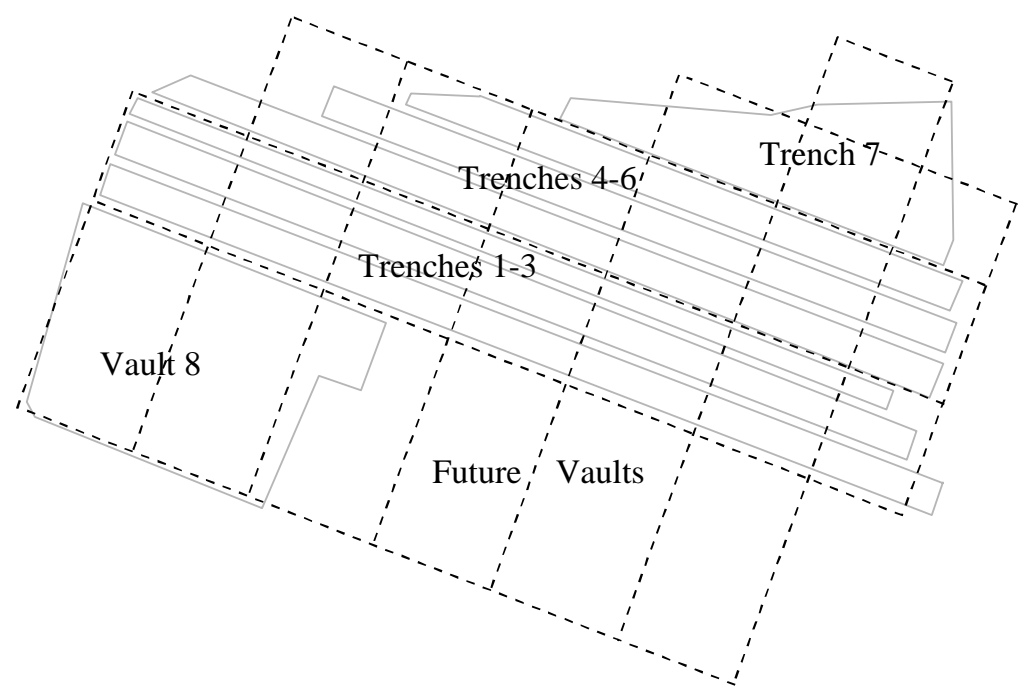

Figure 1. Plan view of the disposition of the Drigg Trench and Vault disposal systems (outlined in grey), and coincidence with the DRINK finite difference grid (dashed lines).

\section{THE DRINK SOURCE TERM MODEL}

The DRINK model utilises the BNFL biogeochemical reaction Generalised Repository Model (GRM) [1,2] to simulate the evolving geochemistry of the Drigg trenches and vaults. GRM considers kinetic controlled steel corrosion and microbial induced cellulose degradation reactions. The products of these processes are used to determine an evolving redox condition, taking account of kinetically controlled microbially mediated redox reactions between product redox species and species in groundwater (e.g. $\mathrm{SO}_{4}$ ) and minerals in soils (e.g. $\left.\mathrm{Fe}(\mathrm{OH})_{3}\right)$. A pe is calculated by using standard mass action equations [3] considering the most oxidising couple. The resulting pe is used as a constraint for equilibrium speciation and mineral equilibrium calculations by a routine based on PHREEQE [4], which determines the evolving $\mathrm{pH}$ and master species concentrations, including those radionuclides which are solubility controlled under the chemical conditions. GRM considers in 2-dimensions the lateral groundwater flow in the saturated zone, using a finite difference solver, the discretisation of the finite difference grid used in the DRINK model is shown in Figure 1. Vertical flow is considered on a cell by cell basis and is used to simulate the release of radionuclides from the unsaturated zone to the saturated zone. In DRINK sorption is modelled using a distribution coefficient $(\mathrm{Kd})$, which can be input on a cell by cell basis, taking consideration of the simulated major element geochemical evolution calculated by the model. Radioactive decay is considered on a cell basis for dissolved, sorbed and precipitated phases, and for the unsaturated zone.

\section{BIOGEOCHEMICAL EVOLUTION OF THE DRIGG SITE}

Chemical evolution of the Drigg trenches is simulated to occur over a period of around 1000 years during which time degradation of cellulose and steel corrosion results in the establishment of conditions more reduced and more acidic than the local groundwater. Figure 2 shows time profiles of example solid and dissolved species concentrations to illustrate the chemical evolution. In the DRINK model the first stage of cellulose degradation is the hydrolysis of cellulose described by a first order kinetic reaction with a $\mathrm{pH}$ dependent hydrolysis constant [2]. The profiles of cellulose concentration (Figure 2a) result from hydrolysis in the saturated zone, together with transfer of cellulose and other materials from the unsaturated zone as a result of settlement. In effect cellulose in the saturated zone is replaced by that in the unsaturated zone until around 100 years 
when the unsaturated zone becomes exhausted; after this time the exponential decrease in cellulose is observed. Iron corrosion is described by a zero order kinetic reaction. Iron concentrations in the saturated and unsaturated zone (Figure 2b) are also subjected to the processes of settlement; in the saturated zone iron increases in concentration because of transfer from the unsaturated zone.

Products of cellulose hydrolysis and corrosion are subject to microbial mediated redox reactions $[1,2]$. Glucose is metabolised by aerobic and anaerobic processes to yield $\mathrm{CO}_{2}$, while acetate and other volatile fatty acids (VFAs) are produced by fermentation. The profile of $\mathrm{CO}_{2}$ production (Figure 2c) is thus a consequence of the process of cellulose degradation and microbial mediated redox reactions, together with gaseous exchange and mineral equilibration reactions. Acetate concentration (Figure $2 \mathrm{~d}$ ) has a similar profile resulting from competition for acetate produced by fermentation, with consumption during redox reactions. Acetate, together with $\mathrm{H}_{2}$ produced during corrosion are the main electron donors in the model which are responsible for the reduction of species such as $\mathrm{SO}_{4}$ in groundwater, and $\mathrm{Fe}$ (III) oxyhydroxide present in disposed soils.

The $\mathrm{pH}$ determined by the PHREEQE speciation calculation (Figure 2e) shows the generation of acidic conditions associated with the formation of $\mathrm{CO}_{2}$ and acetate. After around 800 years $\mathrm{pH}$ returns to that of the local groundwater, which is in equilibrium with calcite at $\log p \mathrm{CO}_{2}=-2$. pe is determined by the $\left[\mathrm{SO}_{4}{ }^{2-}\right] /\left[\mathrm{HS}^{-}\right]$couple for the first 2,000 years of the DRINK simulation, this is significantly more reduced than the local groundwater, whose redox condition is consistent with equilibrium with siderite and Fe(III) oxyhydroxide. After periods of 1,000 to 2,000 years the trenches reoxidise as a result of $\mathrm{NO}_{3}{ }^{-}$present in groundwater, boundary DRINK model cells being the first to reoxidise. The profiles of $\mathrm{pH}$ and pe are inversely related through the Nernst equation, and thus do not clearly indicate the evolution of redox conditions. The concentration profiles of $\mathrm{SO}_{4}{ }^{2-}$ and $\mathrm{HS}^{-}$species however indicate a period of more reduced conditions during the first 1,000 years during which time $\mathrm{HS}^{-}$is the dominant sulphur species (Figure 2f).

The evolving biogeochemical conditions associated with cellulose degradation and steel corrosion involve reactions between minerals considered by the PHREEQE module. A simplified mineral assemblage is considered comprising calcite and $\mathrm{Fe}(\mathrm{III})$ oxyhydroxide representing the reactive component of disposed soil. Under the acidic and reduced conditions simulated for the Drigg trenches calcite and $\mathrm{Fe}$ (III) oxyhydroxide dissolve during the early stages of the model. Siderite precipitates during the first 1,000 years of the model and is the main corrosion product under the simulated conditions, calcite and Fe(III) oxyhydroxide reprecipitates after 800 years as the chemical composition of leachate waters return to that of the local groundwater (Figure $2 \mathrm{~g}$ ).

$\mathrm{pH}$ buffering of the Drigg vaults

The DRINK model cells representing the cementitious vaults are configured in a modified manner to the trenches. Because of the engineered nature of the compacted backfilled vaults, the effect of waste settling is not considered and the unsaturated zone is modelled as the saturated zone, but only considering vertical recharge flow. The chemical buffering effect of the Portland Cement based grout used as a backfill material is simulated by the inclusion of two end-member phases to represent the calcium silicate solid-solution (CSH) [5]. The reaction between these phases is shown in Figure $2 \mathrm{~h}$ and represents a simple carbonation reaction where the calcium rich end member (CEMCSH) reacts with $\mathrm{CO}_{2}$ to produce the silica end member (CEMSIO) and calcite. Two phases of carbonation are evident, a more rapid period during the first 100 years where $\mathrm{CO}_{2}$ generated from cellulose degradation contributes to the reaction, and a slower phase representing carbonation by $\mathrm{CO}_{2}$ present in inflowing groundwater. The calcium end member takes of the order of 10,000 years to be dissolved, during this time $\mathrm{pH}$ is buffered at around $\mathrm{pH} 11\left(\right.$ at $10^{\circ} \mathrm{C}$ ). Despite the establishment of alkaline conditions the vaults are simulated to undergo a similar 


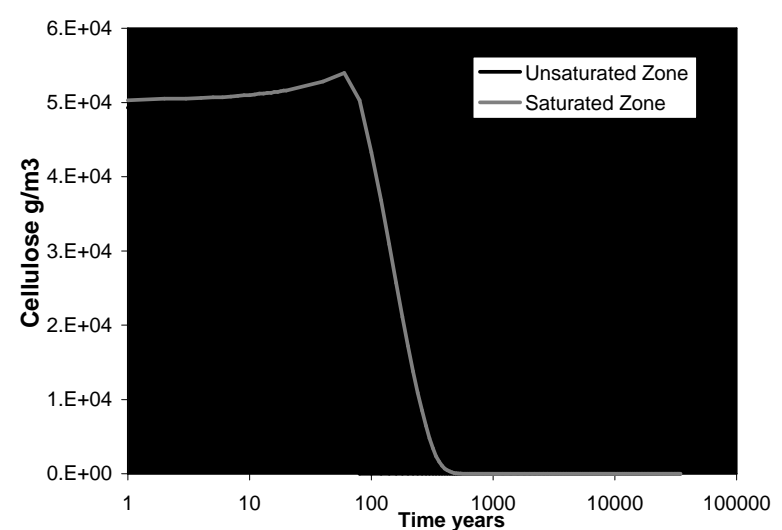

(a)

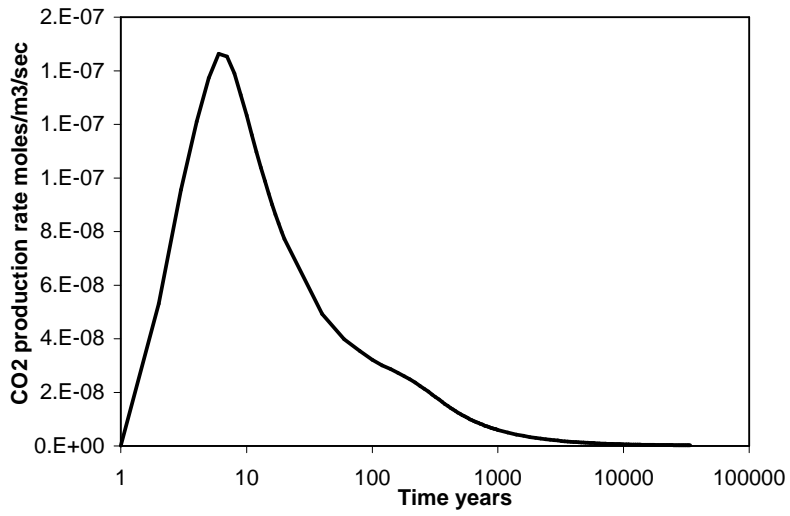

(c)

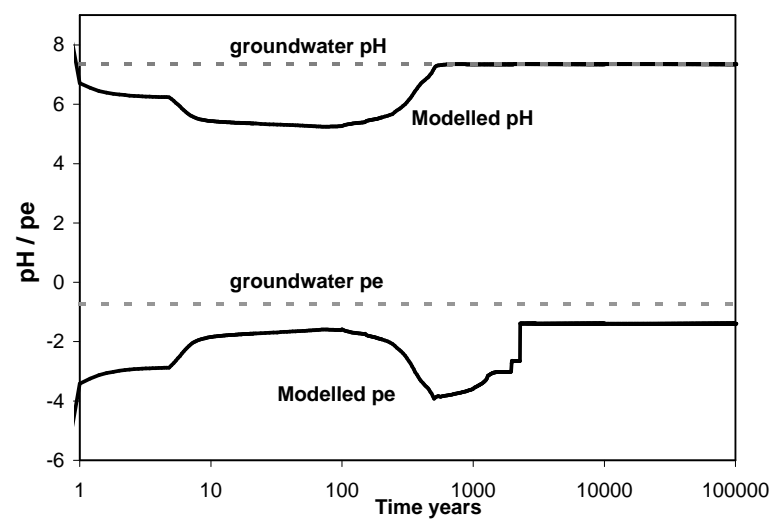

(e)

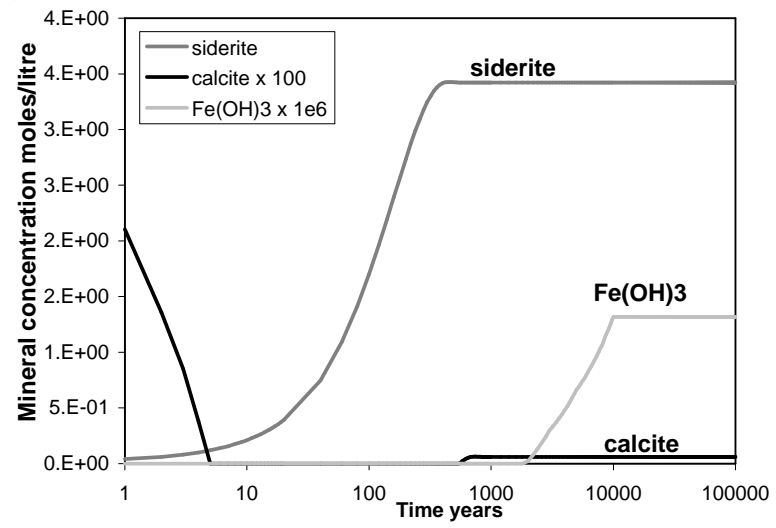

(g)

Figure 2. a-g Concentration profiles of waste materials, and degradation products simulated by the DRINK model for a representative model cell from the Drigg trenches, (h) simulated evolution of cement minerals in the Drigg vault saturated zone.

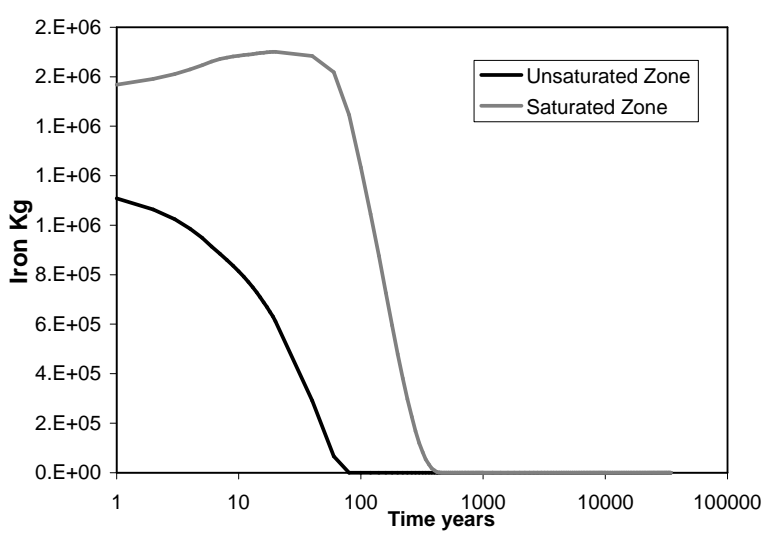

(b)
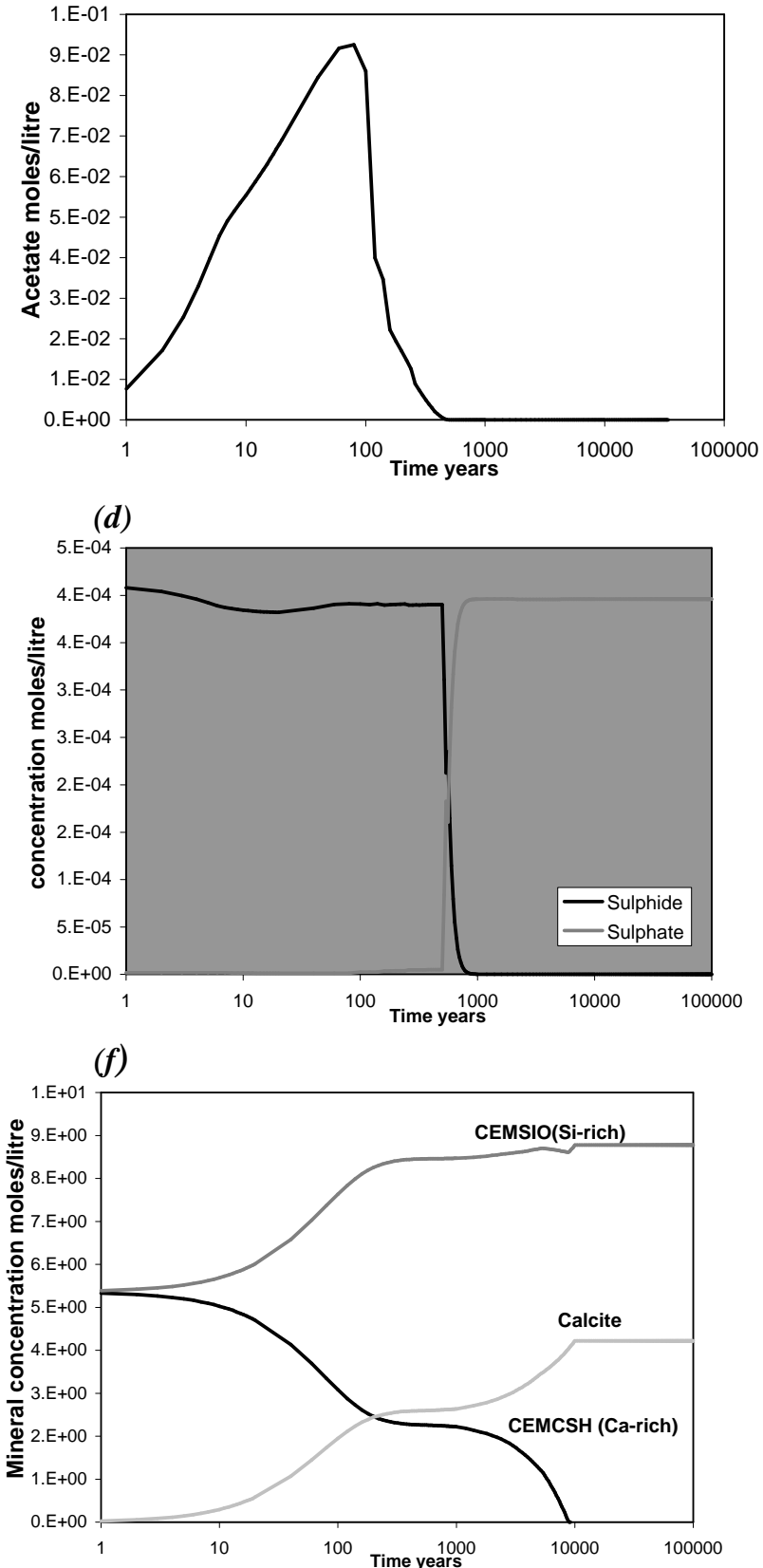

(h) 
pattern of biogeochemical evolution as the Drigg trenches described above. Reduced conditions are established as a result of cellulose degradation and steel corrosion reactions, reoxidation occurs over a period of 2,000 to 10,000 years. Under the alkaline conditions different secondary mineral phases are produced with $\mathrm{Fe}(\mathrm{II})$ hydroxide and $\mathrm{FeS}$ being formed as corrosion products.

\section{RADIONUCLIDE RELEASE MECHANISMS AND NEAR-FIELD CONCENTRATIONS}

The DRINK model uses the evolving major element geochemistry to determine potential solubility controls over radionuclide elements and during these calculations all isotopes of a particular element are combined. The principal solubility controlled radionuclides are Th and $\mathrm{U}$ and their aqueous concentrations under representative trench conditions are illustrated in Figure 3a. Uranium solubilities are simulated to be at minimum values during the first 1,000 years as a consequence of the reduced conditions, which stabilise the U(IV) solid phase $\mathrm{UO}_{2}$. After reoxidation of the trenches $\mathrm{UO}_{2}$ solubility increases as consequence of $\mathrm{U}(\mathrm{VI})$ aqueous speciation. At approximately 30,000 years $\mathrm{UO}_{2}$ completely dissolves and $\mathrm{U}$ concentration decreases sharply. Under the alkaline vault conditions $U$ concentration is solubility controlled at a low concentration (1e-9 to 1e-10 moles/litre) throughout the model. Thorium solubility is very strongly influenced by the generation of high concentrations of acetate during the first 200 years (Figure 2d), with Thacetate being the dominant aqueous species under the acidic conditions of the trenches. When acetate concentration is low, Th concentration is at a low and constant level because of the dominance of the $\mathrm{Th}(\mathrm{OH})_{4}$ species which is unaffected by $\mathrm{pH}$ variation. Under the alkaline vault conditions Th solubility is unaffected by Th-acetate complexing. As a consequence of these solubility controls $\mathrm{U}$ and $\mathrm{Th}$ are retained as solid within the Drigg site. This has important implications for maintaining the concentration of sorption controlled daughter nuclides such as ${ }^{226} \mathrm{Ra}$, (Figure 3a) which increase in concentration over the 1,000 to 30,000 year period, the rate of generation of ${ }^{226} \mathrm{Ra}$ is however lower after 10,000 years when solid $U$ dissolves away. The behaviour of other sorption controlled radionuclides is illustrated in Figure 3b. Sorption controlled release is characterised by a washout of the radionuclide, exemplified by Tc which is assigned a minimal $\mathrm{Kd}$ value. Other radionuclides such as ${ }^{90} \mathrm{Sr}$ are influenced by decay while Am concentration increases as a result of ingrowth of ${ }^{241} \mathrm{Am}$ from ${ }^{241} \mathrm{Pu}$ decay.

(a)

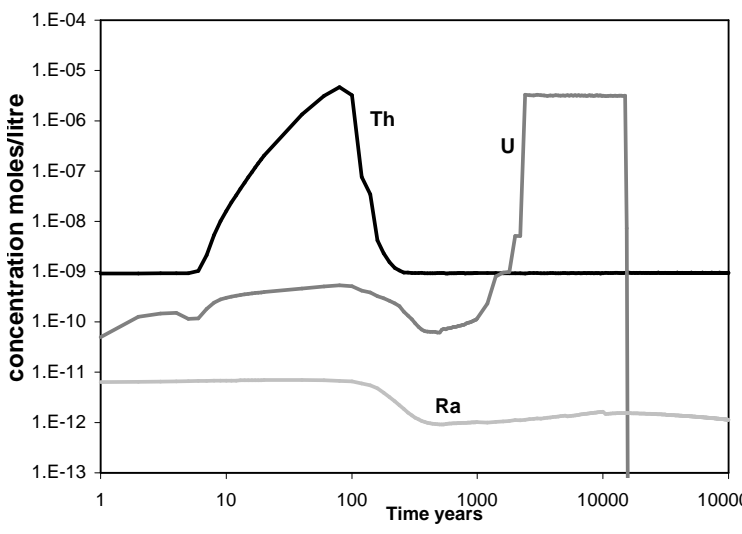

(b)

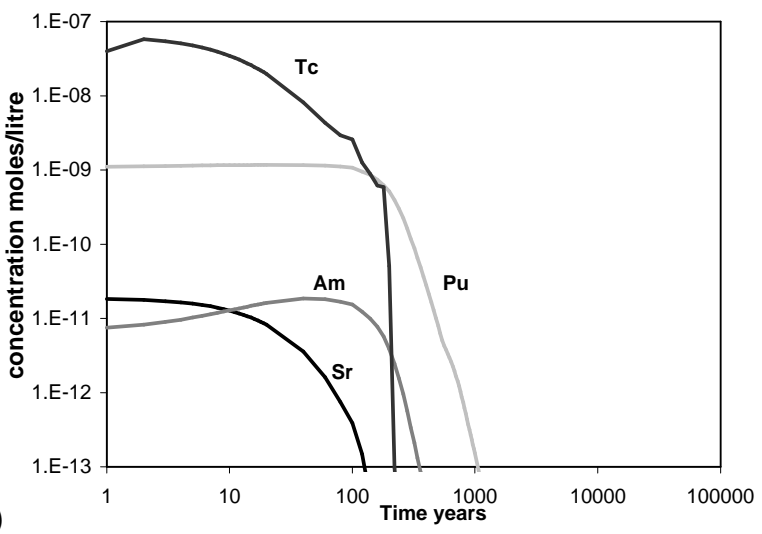

Figure 3. Variation in radionuclide elemental concentrations in the Drigg trenches influenced by (a) solubility controlled processes, and (b) sorption controlled processes.

\section{${ }^{14} \mathrm{C}$ modelling}

Carbon 14 is treated separately from other radionuclides because of the complication of considering the stable isotopes $\left({ }^{12} \mathrm{C}\right.$ and $\left.{ }^{13} \mathrm{C}\right)$ which behave in a virtually identical chemical manner. The approach adopted in DRINK is to assign ${ }^{14} \mathrm{C}$ to the reactive cellulose phase, and to recalculate the fraction of ${ }^{14} \mathrm{C}$ in all carbon species, minerals, gases and microbial substrates at 
each reaction and transport step, but neglecting isotope fractionation effects. The detailed biogeochemical modelling of cellulose degradation and mineral precipitation is therefore central to modelling ${ }^{14} \mathrm{C}$ release. Figure 4 shows the redistribution of the whole ${ }^{14} \mathrm{C}$ inventory during the DRINK simulation. The majority of the ${ }^{14} \mathrm{C}$ is redistributed to siderite and calcite which form as secondary precipitates, approximately $10 \%$ of the inventory remains as inert organic material (humin). Less than $5 \%$ of the ${ }^{14} \mathrm{C}$ inventory is present as acetate or carbonate species, which is thus available for release from the near-field; an even smaller amount is present as gaseous $\mathrm{CO}_{2}$.

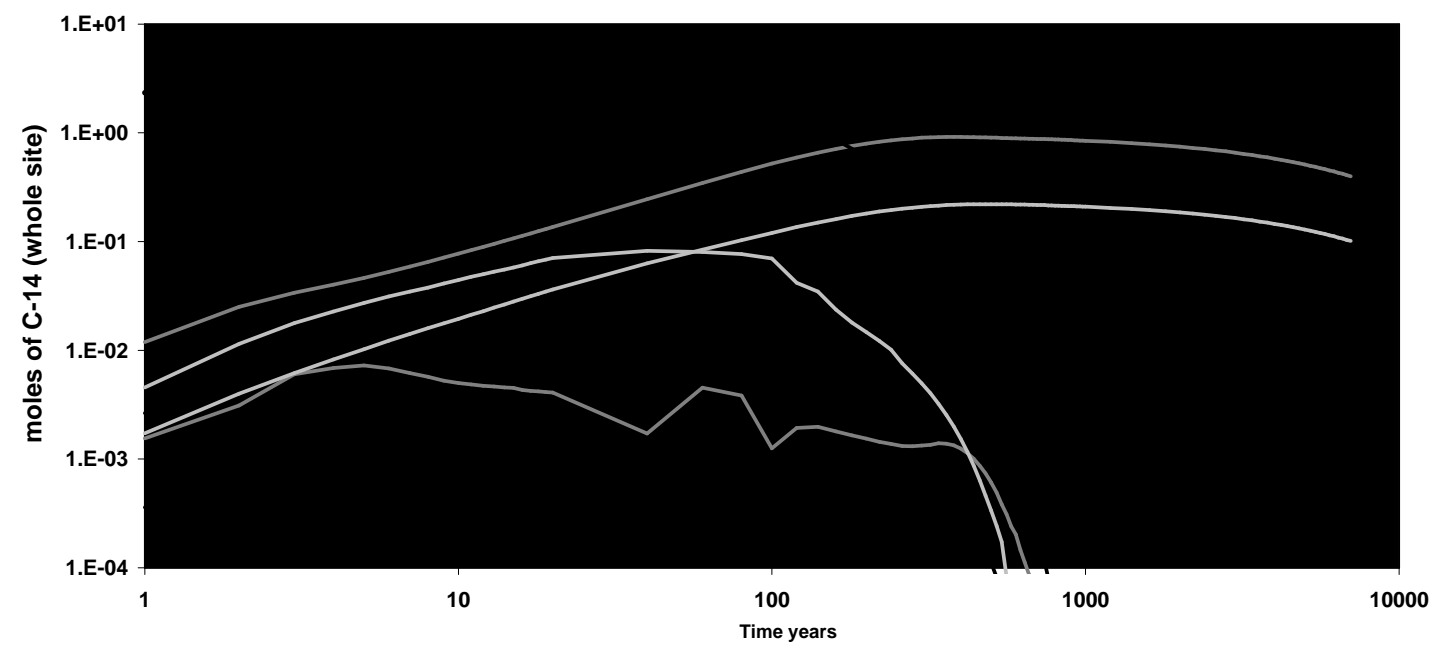

Figure 4. Variation in the distribution of C-14 between solid, aqueous and gaseous species for the whole of the Drigg site.

\section{SUMMARY COMMENTS}

By using independently compiled input data sets derived from site measurements, experimental studies and generic literature, the DRINK model produces a generally credible picture of the biogeochemical evolution of the Drigg trench and vault disposal systems. Certain aspects of this base case biogeochemical model are recognised as being atypical of current site and generic observations. Discussion of these uncertainties is beyond the scope of this paper, however the following are among those currently recognised: corrosion rate, level of acetate, lack of methanogenesis. The effect of uncertainty in model inputs affecting these features and processes is being addressed by sensitivity study. Uncertainties of input parameters such as radionuclide solubilities and $\mathrm{Kd}$ values, which directly affect the source term, also require consideration. Owing to the complexity of considering actinide decay chains and groundwater, gaseous and human intrusion pathways, the full effect of DRINK model uncertainties on radiological impact requires evaluation through the full PCRSA model.

\section{REFERENCES}

1. Manton, S., Johnstone, T., Trivedi, D. P., Hoffmann, A. and Humphreys, P. N., Radiochimica Acta, 68, 75-79 (1995).

2. Humphreys, P. N., Johnstone, T., Trivedi, D. and Hoffmann, A., in Scientific Basis for Nuclear Waste Management XVIII, edited by T. Murakami and R.C Ewing. Mat. Res. Soc. Proc.., 353, 211-218 (1995).

3. Stumm, W. and Morgan, J.J. Aquatic Chemistry. 2nd Ed.. Wiley, New York (1981).

4. Parkhurst, D.L., Thorsteson, D.C. and Plummer, L.N. PHREEQE - A computer program for geochemical calculations, USGS Water Resour.. Invest., 80-96 (1980).

5. Berner, U.R. Waste Management 12, p201,219 (1992). 
This document was created with Win2PDF available at http://www.daneprairie.com. The unregistered version of Win2PDF is for evaluation or non-commercial use only. 